\title{
Artelogie
}

Recherche sur les arts, le patrimoine et la littérature de l'Amérique latine

1 | 2011

Brésil, questions sur le modernisme

\section{A síntese das artes como resgate da vida comunitária.Da Gesamtkunstwerk à nova monumentalidade e o core}

Marcos Antonio dos Santos e Carlos Alberto Ferreira Martins

\section{(2) OpenEdition}

\section{Journals}

\section{Edição electrónica}

URL: https://journals.openedition.org/artelogie/8287

DOI: $10.4000 /$ artelogie.8287

ISSN: 2115-6395

Editora

Association ESCAL

Refêrencia eletrónica

Marcos Antonio dos Santos e Carlos Alberto Ferreira Martins, «A síntese das artes como resgate da vida comunitária. Da Gesamtkunstwerk à nova monumentalidade e o core», Artelogie [Online], 1 | 2011, posto online no dia 01 março 2011, consultado o 07 janeiro 2022. URL: http://

journals.openedition.org/artelogie/8287 ; DOI: https://doi.org/10.4000/artelogie.8287

Este documento foi criado de forma automática no dia 7 janeiro 2022.

Association ESCAL 


\title{
A síntese das artes como resgate da vida comunitária.Da Gesamtkunstwerk à nova monumentalidade e o core
}

\author{
Marcos Antonio dos Santos e Carlos Alberto Ferreira Martins
}

\section{Introdução}

1 A retomada das discussões sobre arquitetura e urbanismo dentro dos CIAM's Congresso Internacional de Arquitetura Moderna, no segundo pós-guerra, teve como objetivo tanto a defesa de uma arquitetura e urbanismo de raiz racionalista, baseados nas formulações da velha geração de arquitetos dos congressos, quanto o questionamento dos postulados desta pela nova geração que tomava parte das discussões nos CIAM's.

2 De certa forma, este processo de revisão crítica começara antes do fim da Segunda Guerra Mundial, quando da publicação do manifesto Nine Points on Monumentality, escrito a seis mãos por J. L. Sert, F. Léger e S. Giedion em 1943. A discussão proposta pelos "Nine Points" colocava a idéia da significação coletiva do monumento e sua desaparição das preocupações dos arquitetos e urbanistas modernos que haviam se "revoltado" contra a idéia de monumentalidade. Discutia, também, a primazia dada ao arquiteto nas formulações do entre-guerras apontando para a necessidade de colaboração entre vários profissionais na concepção da arquitetura e do urbanismo, o que recolocava a discussão sobre a síntese das artes.

De outro lado, a nova geração de arquitetos propôs temáticas que, de certa forma, questionavam ou até mesmo invalidavam parte do imaginário moderno em arquitetura e urbanismo oriundo das discussões ocorridas dentro dos CIAM's do entre-guerras. Centro comunitário versus Centro Cívico, planejamento urbano tendo como base o conceito de escala no lugar do zoneamento rígido, tido como subproduto da Carta de 
Atenas, eram apenas alguns dos pontos que colocavam a velha guarda e os novos membros dos CIAM's em lados opostos.

4 Monumentalidade, core e síntese das artes, temáticas que a priori tratavam elementos diversos, tinham o resgate da comunidade como idéia central. Mais facilmente perceptível nas discussões sobre o core e a nova monumentalidade portadora de significados coletivos, a idéia do resgate dos ideais comunitários esteve na raiz da idéia de síntese das artes.

5 O presente trabalho tem a intenção de resgatar a presença da idéia de comunidade nas discussões sobre a integração ou síntese das artes e, posteriormente, entender sua importância tanto para a geração modernista "heróica" quanto para a geração de arquitetos do segundo pós-guerra, crítica dos processos de urbanização baseados no Racionalismo Funcionalista.

\section{O conceito Síntese das Artes}

6 Síntese das artes ou integração das artes, conceitos centrais para as discussões das Vanguardas Artísticas sobre arte e cidade, trazem em seu bojo a idéia do resgate do ideal comunitário de maneira indissociável.

O ideal de uma experiência artística que pudesse ser a manifestação de todas as artes em sintonia é devedor do conceito de Gesamtkunstwerk ${ }^{1}$ formulado por Richard Wagner na segunda metade do Séc. XIX².

8 Wagner ao imaginar o teatro grego como um exemplo de obra de arte total, ou um exemplo de síntese das artes, teorizava sobre questões já trabalhadas séculos antes por compositores do alto Barroco quando procuraram resgatar a cultura grega na transição para o Classicismo.

9 Vincenzo Galilei, Giovanni Caccini e por fim Jacopo Peri buscaram uma forma de representação teatral que, partindo da suposição de que os gregos assim o faziam, conseguisse proporcionar a recuperação da arte dramática da antiga Grécia. Representação esta que se apresentasse como uma forma de fazer artístico no qual as artes se manifestassem em comunhão. Jacopo Peri foi autor da primeira ópera conhecida, uma tentativa de reviver a tragédia grega clássica, como parte de uma ampla reaparição da antiguidade clássica que caracterizou o Renascimento ${ }^{3}$.

10 A retomada desta discussão por Wagner na segunda metade do Séc. XIX se identifica com o descontentamento dos pensadores das mais diversas áreas com as promessas não cumpridas pela vida urbana pós-revolução industrial. Para Schorske, o século XIX foi o século da história, em detrimento ao século XVIII que para ele se configurou como o século da filosofia. De maneira que o ideal da cidade virtude foi característico do período dominado pela razão - século XVIII e a filosofia, ao passo que a cidade vício ficava identificada com o século XIX e a constatação do não cumprimento das promessas esboçadas pelo Iluminismo4.

11 É na constatação das reais condições de vida nas cidades, em contrapartida a todo um potencial emancipatório relativo à vida urbana, que se deram as orientações dos pensadores da cidade. Como exemplo desta relação entre uma promessa não cumprida pela vida metropolitana e certa nostalgia da comunidade perdida, Schorske estabelece a ligação entre o Arts and Crafts de Morris e as discussões wagnerianas, ainda que seu desenvolvimento tenha se dado em direções opostas. Morris e Wagner buscavam a cura 
dos males de sua época, sinônimo de desencanto com a civilização moderna, tomando como ponto de partida o resgate de uma visão comunitária perdida após a Revolução Industrial. Para o primeiro, o mito de origem de uma suposta comunidade era a forma de produção artesanal medieval, enquanto para Wagner, era a idéia de que na antiga tragédia grega os elementos música, teatro, canto, dança e artes plásticas estavam unidos, mas, em algum momento, separaram-se.

Morris foi responsável pela aplicação do conceito de síntese das artes ao design e à arquitetura. Propôs uma arte que se estendesse a todas esferas da sociedade, uma arte que estivesse presente nos objetos de uso quotidiano e no ambiente da vida. ${ }^{5}$

13 As discussões, tanto de Wagner quanto de Morris, não estiveram sozinhas durante o Séc. XIX. Imaginar uma forma de permitir o crescimento urbano sem que características consideradas positivas da vida na comunidade se perdessem foi, em grande medida, a tônica das discussões sobre as cidades desta época.

O Falanstério de Charles Fourier, que atualizava de maneira radical o discurso da Viagem à Ilha da Utopia de Thomas More, ou mesmo a breve existência de New Harmony de Robert Owen se enquadram nesta tentativa de auferir as vantagens do viver moderno sem perdas das qualidades da vida na comunidade. Uma tentativa, com uma perceptível marca platônica, de impor ética à vida urbana mediante a prédeterminação das atividades sociais.

15 As questões sobre Gesamkunstwerk/Síntese das artes estiveram presentes nas discussões sobre arquitetura e design dos Séculos XIX e XX, percorrendo um arco temporal que abarca o Arts and Crafts e deságua na Bauhaus. A Vanguarda sempre foi tributária da noção de Gesamtkunstwerk e a Bauhaus nasceu diretamente desta tradição.

\section{Vanguardas e a utopia de integração/dissolução de arte na vida}

16 A aproximação entre arte e vida e concepção moderna de síntese das artes é tema central das propostas das vanguardas artísticas do início do século $\mathrm{XX}$, tais como o Neoplasticismo, o Construtivismo Russo e a Bauhaus. Estes buscavam, a partir de sua dimensão utópica, transcender as separações entre pintura, escultura e arquitetura.

17 Uma análise da Bauhaus possibilita o entendimento da escola alemã como uma das principais influências para que se incorporasse a idéia de síntese das artes no pensamento moderno. Em grande parte isto se deveu ao partido metodológico adotado na escola, que visava a aproximação entre pintura, arquitetura e escultura. Além do sucesso obtido neste aspecto, a escola logrou também a elevação da qualidade estética do design e da arquitetura produzidos em massa pelos modernos processos de produção industrial. A Bauhaus se constituiu como um espaço no qual a formação dos artistas e arquitetos teve como central a necessidade da comunicação entre as artes. $O$ que possibilita o entendimento da Bauhaus como uma câmara de decantação das vanguardas européias, na qual o ideal de uma grande obra coletiva, transformadora da própria organização social, será forjado a partir da unidade entre as artes.

18 No manifesto de fundação da Bauhaus, a adesão à "obra de arte total" direciona um trabalho conjunto em que a arquitetura exerce papel fundamental : A idéia da catedral gótica como lócus privilegiado da Gesamtkustwerk soma-se ao paradigma da máquina para a efetivação da arquitetura como "grande construção", como reunificação das 
disciplinas artísticas e fruto de diferentes contribuições regidas por um sentido de consenso e unidade. ${ }^{6}$

19 A cooperação entre as artes é proposta a partir do canteiro, onde arquitetos, escultores e pintores trabalhariam em conjunto com marceneiros, pedreiros, carpinteiros para a criação de uma obra coletiva, tomando como modelo a catedral, propondo assim a unidade entre arte e política. A finalidade última, mesmo que remota, da Bauhaus é a obra de arte unitária - a grande arquitetura.

Para Gropius, a construção completa deveria ser o objetivo final das artes visuais. As artes que atuaram em isolado com o único objetivo de decoração dos edifícios, tinham agora que atuar em conjunto, em uma comunidade de artistas reunindo arquitetura, escultura e pintura numa única unidade. ${ }^{7}$

Da arquitetura para a cidade o caminho era mais que natural, a atualização dos textos utópicos, como é visível nos trabalhos de Le Corbusier, transfigurou-se no desejo de encurtar os sonhos de uma cidade possível, racionalmente construída e sem a presença do acidental. Le Corbusier talvez seja o exemplo mais contundente de como os conceitos artísticos podem se constituir como meios ativos de intervenção em concepções arquitetônicas, que sugerem a importância e eficácia da integração ou diálogo entre arte e arquitetura. A partir dos Anos Vinte sua arquitetura reflete a utilização dos descobrimentos formais e plásticos na ordenação dos espaços, ocorridos anteriormente em sua atividade como pintor.

Nas obras de Le Corbusier posteriores a 1945, como a Unité d'Habitation de Marselha, a Capela Notre-Dame du Haut em Ronchamp, os edifícios em Chandigarh, culminando com o Pavilhão Philips de 1958, os temas são trabalhados tendo em mente o conceito de arte construída. Os edifícios e sua estrutura são modelados como uma escultura, a cor é aplicada de forma generosa, pinturas, tapeçarias e até meios de comunicação audiovisual tornam-se integrantes da arquitetura, subordinados à idéia arquitetônica com o objetivo de obter uma síntese das artes.

Para Le Corbusier a monumentalidade moderna se realiza com a síntese entre a arquitetura e outras "artes maiores" : a pintura mural e a escultura. A introdução de elementos murais e esculturais oferecia à arquitetura recursos expressivos que iam além da linguagem abstrata e técnica do funcionalismo ${ }^{8}$.

\section{CIAM's do Segundo Pós-Guerra}

\section{Síntese das artes, Monumentalidade e Core}

Durante a primeira metade do Século XX os Congressos Internacionais de Arquitetura Moderna - os CIAM's - funcionaram como caixa de ressonância das preocupações dos arquitetos, urbanistas e estudiosos da vida nas cidades. Fundados em 1928 em La Sarraz, Suíça, os Congressos tiveram suas atividades suspensas devido à eclosão da II Guerra Mundial.

O congresso de 1933 em Atenas produziu o "o documento mais olímpico, retórico, essencialmente destrutivo que já surgiu dos CIAM : a Carta de Atenas". As correções endereçadas às condições de vida nas cidades, feitas na "Carta", são agrupadas sob cinco categorias principais : Moradia, Lazer, Trabalho, Transporte e Edifícios Históricos 9 . 

dogmático associado à "Carta" e sua suposta aplicabilidade universal comprometeram os CIAM's quanto à sua concepção arquitetônica e urbanística. 0 ideário racionalista presente na Carta, passou a identificar os Congressos como um todo. Segunda Guerra, Sigfried Giedion, Fernand Léger e José Luis Sert elaboraram os "Nove Pontos sobre a Monumentalidade". A arquitetura que havia expulsado os artistas dos grandes empreendimentos públicos deveria reclamar sua participação para a construção de uma nova monumentalidade que sirvisse de elo entre passado e futuro. 0 monumento como "um espírito ou sentimento coletivo" expressão de uma força coletiva. Nos documentos de Giedion, Sert e Léger a "força coletiva" aponta para a produção do espaço como possibilidade de resgate das relações comunitárias, seus desenvolvimentos posteriores, dentro dos CIAM's, deixaram mais claras suas relações com o tema da síntese das artes.

O resgate de uma vida comunitária também se faz ouvir no manifesto de 1943. Partindo da ágora, como exemplo de monumento e de centro comunitário, os autores denunciam que no mundo contemporâneo não consegue construir monumentos que tenha significação coletiva. E que a arquitetura deveria se esforçar para a realização de monumentos plenos de significa uma vez que as pessoas têm desejo d uma monumentalidade que vá além da mera realização da funcionalidade. Procuram a expressão de suas aspirações em monumentalidade, pela alegria e pela emoção. ${ }^{10}$

Arquitetura, este meio mais "sensível de expressão plástica para o povo" deveria então se ocupar de edifícios que representassem "a vida comunitária, social e cerimonial", possibilitando "o contato pessoal fundamental para desenvolver a vida comunitária". Deveria "criar os seus centros comunitários" como reais monumentos de significação coletiva. 0 que colocaria a arquitetura em consonância com os desejos da maioria, uma vez que "as pessoas querem que os edifícios que representam sua vida social e comunitária proporcionem algo além da mera satisfação funcional". ${ }^{11}$

30 Aliado ao conceito de monumentalidade, nas discussões propostas por Nine Points on Monumentality, fica claro também o desejo de um processo de produção da arquitetura que possibilitasse a integração do trabalho do planejador, arquiteto, pintor, escultor e paisagista, exigindo uma estreita colaboração entre todos eles. Esta colaboração teria falhado nos últimos cem anos. A maioria dos arquitetos modernos não teria sido treinada para este tipo de trabalho integrado. Esta tarefa monumental não lhes foi confiada.

31 No CIAM VIII, realizado em 1951 na cidade de Hoddesdon na Inglaterra, desenvolve-se o tema do core - $\mathrm{O}$ coração da cidade. Este core seria uma espécie de fórum ou ágora, o espaço público por excelência, sobretudo o lugar do pedestre, voltado para a produção do espírito. 0 espírito comunitário aparece então como orientador da produção da cidade.

O espaço público visto como lugar de encontro e possibilidade de trocas intersubjetivas, no qual a experiência pessoal entre os habitantes, reunidas livremente em praças, passeios, cafés, cassinos populares, etc., fosse além das possibilidades oferecidas pelos novos meios de comunicação. ${ }^{12}$

33 Lúcio Costa, membro dos CIAM's desde os Anos de 1930, tomou contato com tais discussões e tratou de colocá-las na ordem do dia das discussões brasileiras. Era visível 
que o arquiteto que projetaria na mesma década a nova capital tomara contato com as revisões dos CIAM's do segundo pós-guerra. A substituição do dado quantitativo pelo qualitativo, a ênfase na questão da cidade como fato histórico, o respeito a individualidade mesmo encarando a questão coletiva do fenômeno urbano, são questões que demonstravam a atualização de um arquiteto formado dentro dos cânones da Carta de Atenas. ${ }^{13}$

34 A confecção do documento de 1943, demonstra uma mudança ocorrendo por dentro dos CIAM's, e ao mesmo tempo abre as possibilidade para uma discussão mais ampla na qual a idéia da comunidade aparece imbricada nas discussões sobre a nova monumentalidade, o core e arquitetura como síntese das artes.

Cidade, arte e arquitetura pensadas a partir do ideal de comunidade. Seguindo a trilha inaugurada pelos "Nove Pontos", ainda em 1943, Fernand Léger advoga em favor da arquitetura se abrir como um campo de experimentação para a utilização da cor pintura. ${ }^{14}$

36 Se, na fase heróica do Modernismo arquitetônico, o expurgo do ornamento e de tudo o que se agregasse à arquitetura de forma a esconder a pureza de suas formas foi a tônica das discussões, a exemplo dos manifestos de Adolf Loos e Le Corbusier, o clima do segundo pós-guerra favorecia francamente a revisão destes postulados.

37 Le Corbusier, idealizador do Purismo, apresentou uma conferência no Congresso Internacional de Artistas em Veneza, em 1952, na qual os arquitetos contemporâneos deveriam repensar a síntese das artes, devolvendo à arquitetura o seu antigo papel de geradora e integradora das artes.

No segundo pós-guerra convém ressaltar a contribuição de Lucio Costa sobre esta temática no debate arquitetônico internacional. o brasileiro tinha reservas quanto à expressão síntese das artes, que para ele indicaria fusão. Costa preferia o termo integração, nesse caso, a obra de arte se agregaria harmoniosamente à arquitetura, desde a concepção do projeto.

Lúcio Costa, quando, no texto $O$ Arquiteto e a Sociedade Contemporânea questionava a atuação de alguns pintores que usariam a arquitetura apenas como cenário para suas obras, sem maior atenção para uma postura de integração. Costa acentuava a necessidade de que a obra do pintor e do escultor devia integrar-se ao conjunto da composição arquitetural como um dos seus elementos constitutivos, ainda que esta obra mantivesse autonomia e caráter próprios. Apontava ainda, como fator essencial, pensar a arquitetura na sua dimensão plástica, preservada a dimensão específica de cada fazer artístico.

Costa, de forma bastante próxima às proposições das vanguardas do início do século, apresenta a idéia de síntese das artes tendo a arquitetura como fio condutor, pois para ambos, é ela que fornece materialidade à cidade.

41 Nos últimos CIAMs, as discussões sobre arquitetura deveriam passar pela revisão e ampliação de seus tópicos programáticos e ainda pela absorção da nova complexidade da vida urbana do segundo pós-guerra. 0 discurso urbanístico interessa-se então por problemas relativos à humanização da cidade, pensada agora mediante ideais comunitários, em oposição à estrita produtividade urbana exigida pelo urbanismo do entre-guerras. Nesse momento ressurge com força absoluta a idéia da cidade e da arquitetura em processo de comunhão com as demais artes. 


\section{Arquitetura brasileira e a síntese das artes}

\section{MESP, Pampulha e Brasília}

Le Corbusier é, sem dúvida, paradigma para a construção do pensamento moderno no Brasil e conseqüentemente referência imediata no que se refere à integração das artes. A visita do arquiteto franco suíço deixou grandes influências sobre o grupo de jovens arquitetos capitaneados por Lúcio Costa.

Arquitetura Moderna no Brasil, caracterizada pelo trabalho integrado de pintores, escultores, arquitetos e paisagistas é, segundo Fernandes, devedora da estadia de Le Corbusier no Brasil em 1936 e sua participação no projeto para o edifício do Ministério da Educação e Saúde, onde se destacam as contribuições de Lúcio Costa e Oscar Niemeyer ${ }^{15}$.

No Ministério é decisiva a inclusão das artes plásticas (pintura, escultura e paisagismo) no vocabulário arquitetônico moderno, como paradigma na aproximação entre arte e arquitetura deste período. ${ }^{16}$

No MESP são incorporados à arquitetura trabalhos de artistas plásticos, como o painel de azulejos de Cândido Portinari, que qualifica os volumes no nível térreo do edifício e faz referência a motivos marinhos próprios da cidade a beira mar onde se situa. As esculturas de Bruno Giorgi também encontram lugar adequado no conjunto, todo emoldurado pelos jardins de Burle Marx, que buscam formas novas a partir das texturas da vegetação tropical.

Síntese que não se faz gratuitamente, segundo Lúcio Costa, o papel das obras de arte na composição arquitetônica é também definido pela função que cada uma delas cumpre. ${ }^{17}$

Figura 1 - Painel de azulejos de Cândido Portinari

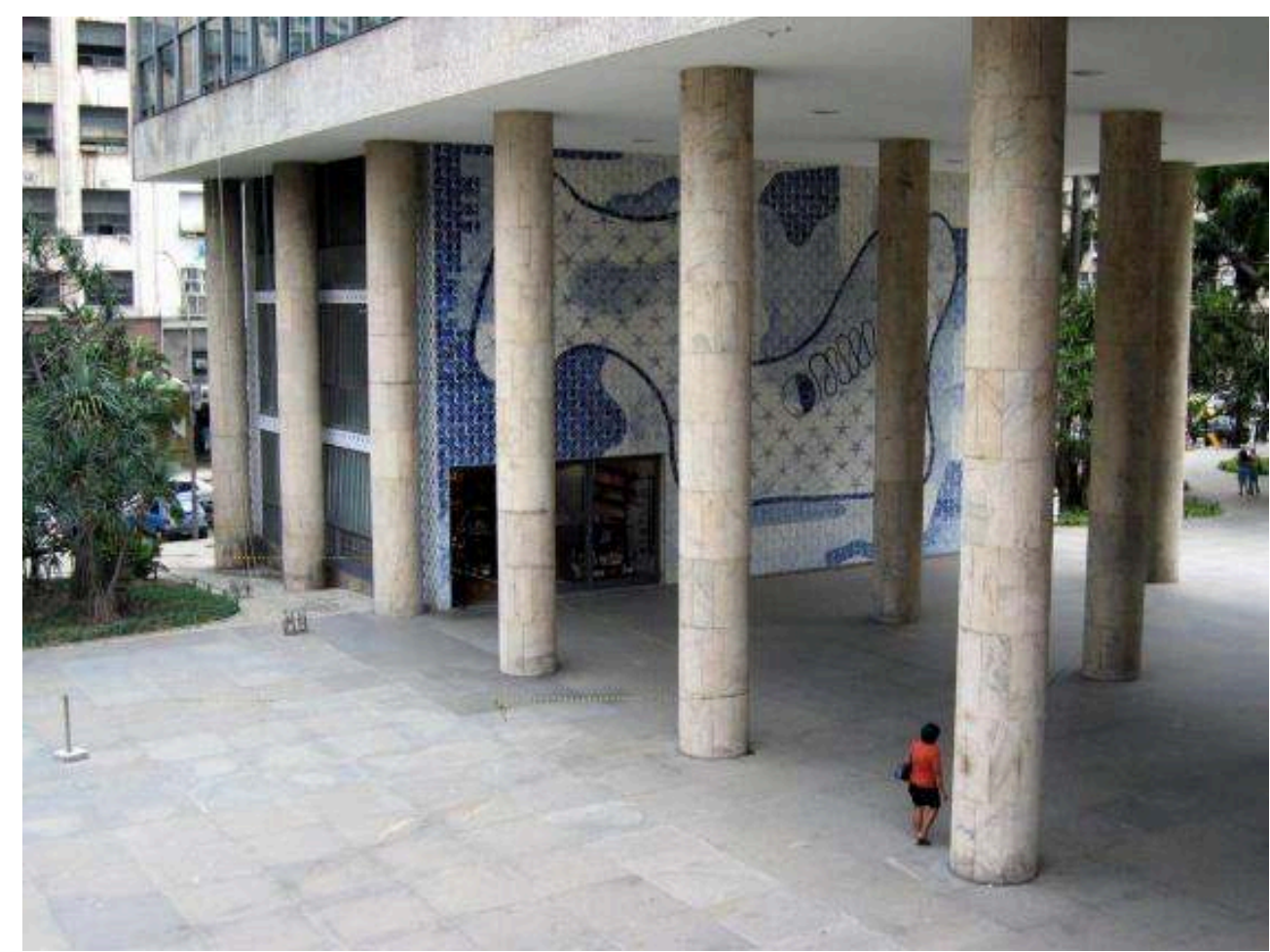



idéia de arquitetura como síntese das artes estivesse sempre presente. Diversos foram os exemplos construídos nos quais a possibilidade de expressão artística já estava presente. ${ }^{18}$

A Capela de São Francisco possui a mais conhecida obra de arte do complexo da Pampulha, o painel de azulejos de Cândido Portinari, com motivos religiosos alusivos à trajetória de São Francisco de Assis. De todo o complexo da Pampulha é na capela que o tema da integração das artes, colaboração entre artistas e arquitetos, teve o seu maior êxito.

\section{Figura 2 - Igreja da Pampulha}

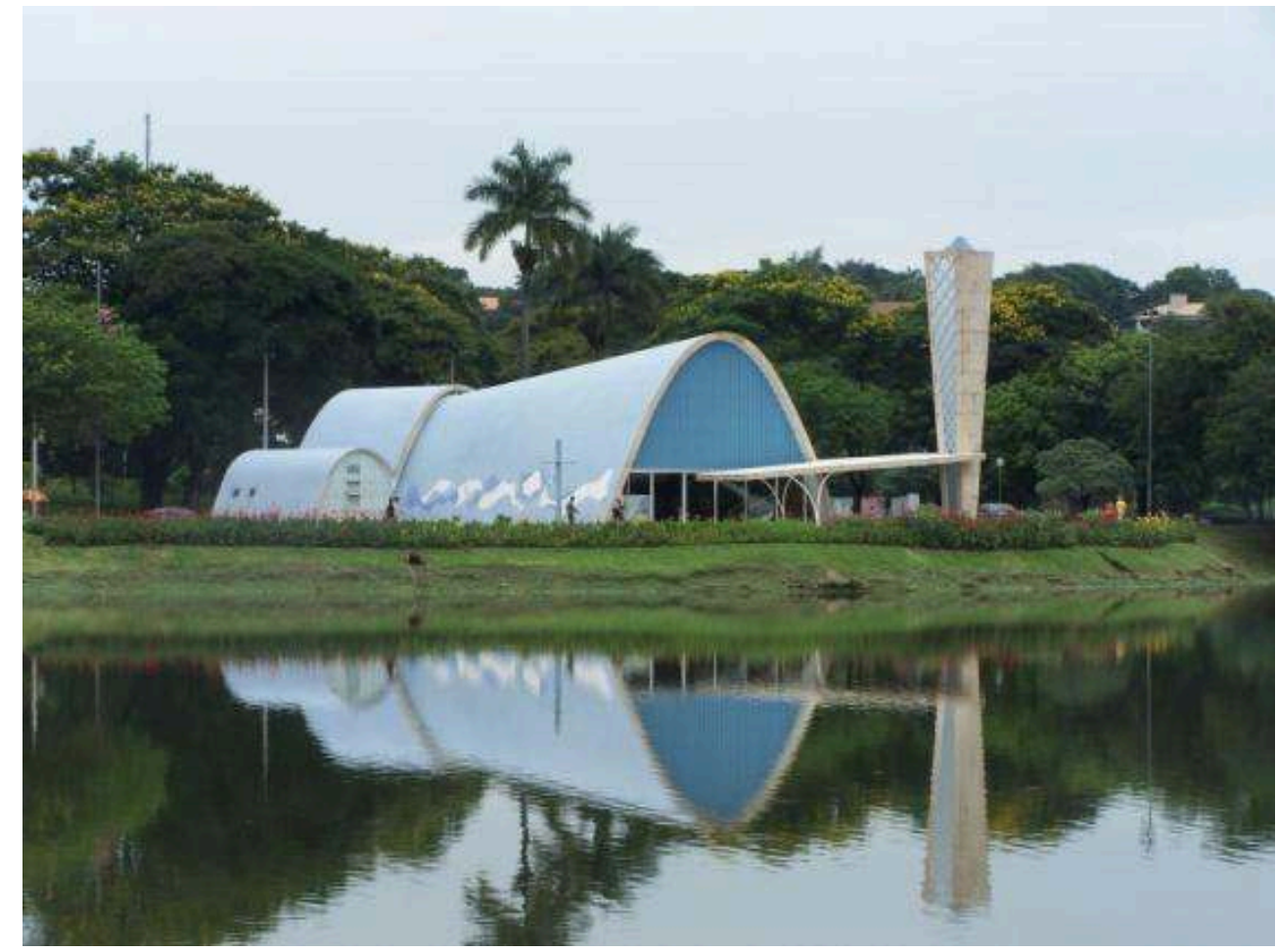

A Igreja São Francisco de Assis, na Pampulha, possui em sua fachada um painel de azulejos, em tons azuis, de autoria de Cândido Portinari. No interior - confessionário, batistério, coro, púlpito e nas bancadas laterais - existem outros Painéis de Azulejos criados por Portinari. Nas laterais da Igreja, fazendo parte do telhado, há Painéis de Pastilhas, abstratos, do artista Paulo Werneck, autor de inúmeros outros trabalhos semelhantes, principalmente na cidade do Rio de Janeiro. Os jardins que circundam a Igreja foram projetados por Burle Marx. 
Figura 3 - Painel de Azulejos de Cândido Portinari na Igreja da Pampulha

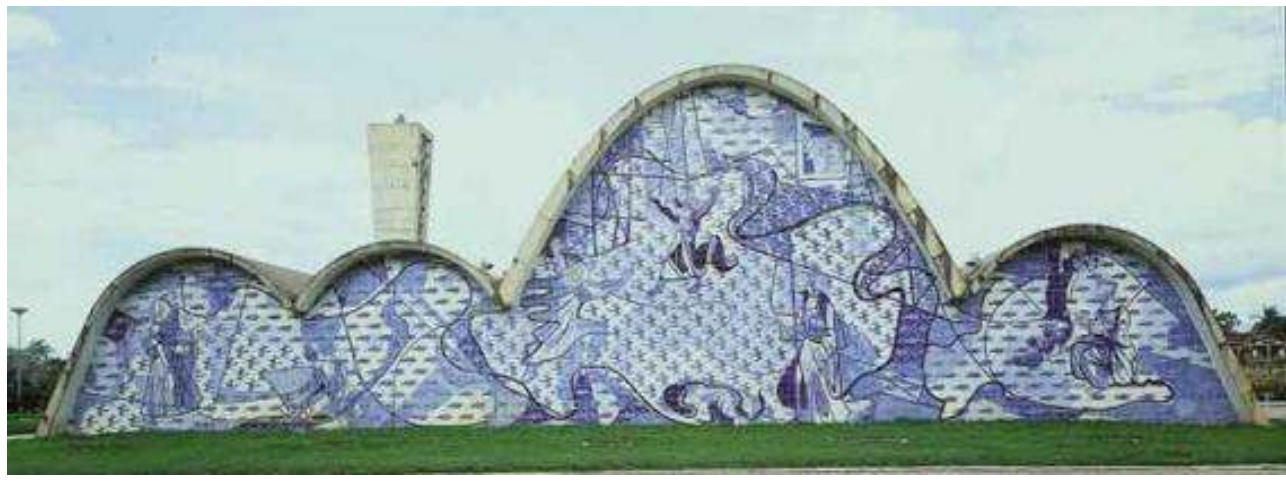

Brasília, por sua vez, é vista por Pedrosa como obra de arte coletiva, que abarca num mesmo conjunto as dimensões urbanísticas e arquitetônicas, um empreendimento que se refere à totalidade social, cultural e artística do país, e convoca a participar de sua realização todas as artes desde as mais nobres até as mais particulares e utilitárias. Pedrosa esclarece que esta aspiração artística e estética é revestida de um valor ético, na medida em que busca restituir ao homem contemporâneo, em sua vida atribulada e neurótica, novos parâmetros de convivência direcionados à "recuperação da harmonia e comunhão espiritual". ${ }^{19} 20$

Figura 4 - 0 Eixo Monumental visto da Torre de TV de Brasília

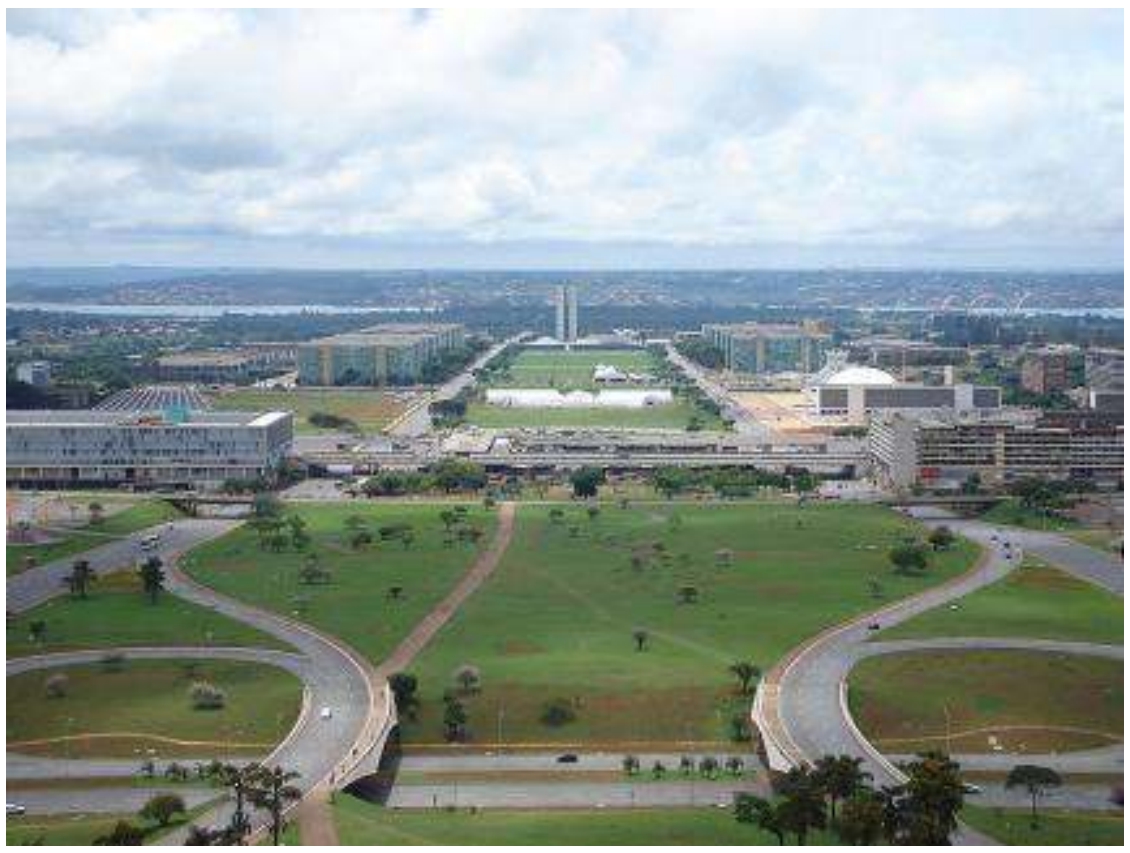

Um dos exemplos mais conhecidos dos edifícios brasilienses pensados a partir do conceito de síntese das artes, o Palácio Itamaraty tem em seu interior painéis de artistas como Athos Bulcão, Rubem Valentim, Sérgio Camargo, Maria Martins e afresco de Alfredo Volpi. o paisagismo interno e externo é de Roberto Burle Marx. Em frente ao Palácio do Itamaraty, sobre o espelho d'água, encontra-se a escultura Meteoro, desenhada por Bruno Giorgi. 
Figura 5 - 0 Meteoro, uma escultura em mármore de Bruno Giorgi, Palácio do Itamaraty

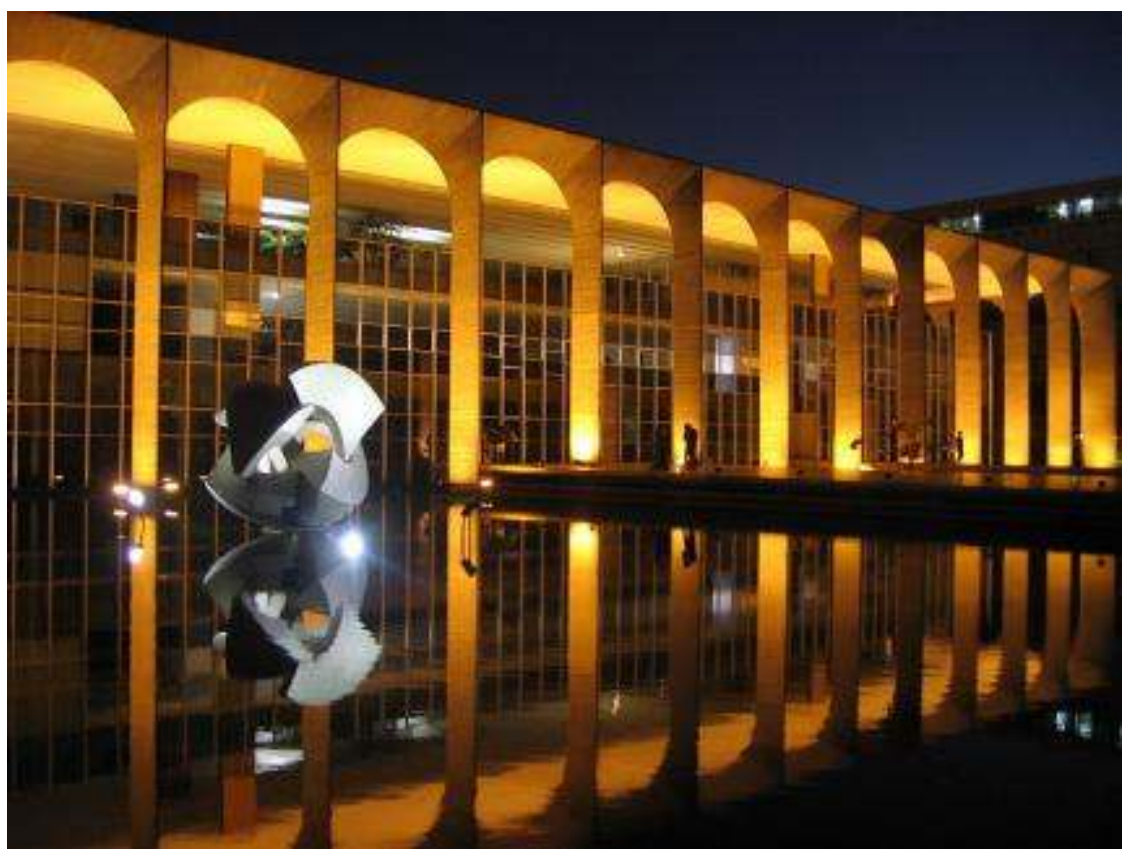

Brasília foi concebida para ser, na essência, uma obra de arte coletiva em pleno planalto central. A cidade se tornaria obra de arte coletiva, porque todas as atividades de todos os homens ao habitá-la, seriam conformadas pelo planejamento, eliminando-se o laissez-faire e o empirismo da razão colonial portuguesa.

\section{São Paulo - Síntese das Artes}

Num contexto caracterizado pelo crescimento urbano e industrial - processo que tem a capital paulista como epicentro, a utopia construtiva de socialização da arte por meio da indústria, bem como a crença no papel restaurador da arte moderna, encontra adeptos nos principais centros urbanos do país. ${ }^{21}$

54 A Segunda Grande Guerra desempenhou um papel preponderante na questão do resgate dos ideais comunitários e da hipótese de integração entre as artes através da arquitetura e da participação social do artista na constituição do ambiente urbano. Muitos artistas viram a arte concreta e o desenho industrial como uma forma de intervenção racional e positiva num mundo ainda traumatizado diante das questões éticas e sociais suscitadas pelo conflito mundial.

Em São Paulo, somou-se a este quadro histórico o fato da comemoração do IV Centenário de sua fundação. Inúmeras obras foram construídas tendo as comemorações como foco. Obras de caráter francamente ufanista do sentimento paulista foram a forma encontrada para celebrar o aniversário da cidade e reocupar o espaço perdido durante os Anos Vargas, demonstrando a força do Estado, tido como a locomotiva do Brasil. Inserem-se neste caráter obras como o Monumento das Bandeiras e o Parque do Ibirapuera.

o Parque do Ibirapuera, espaço de 1,5 milhões de metros quadrados, que se tornou uma referência na metrópole paulistana, tem projeto arquitetônico de Oscar Niemeyer e o paisagismo sob a autoria de Roberto Burle Marx. Oscar Niemeyer foi responsável por 
grande parte dos projetos construídos para as comemorações do aniversário de São Paulo, e também após os festejos, durante os Anos de 1950-1960. Dentre estes se destaca, o Edifício Triângulo, projetado por Oscar Niemeyer e inaugurado em 1955, um edifício comercial localizado no centro de São Paulo, no cruzamento das ruas José Bonifácio e Quintino Bocaiúva. A entrada principal é recoberta por um grande um painel de pastilhas de Di Cavalcanti.

Figura 6 - Mural de Di Cavalcanti, na fachada do Edifício Triângulo

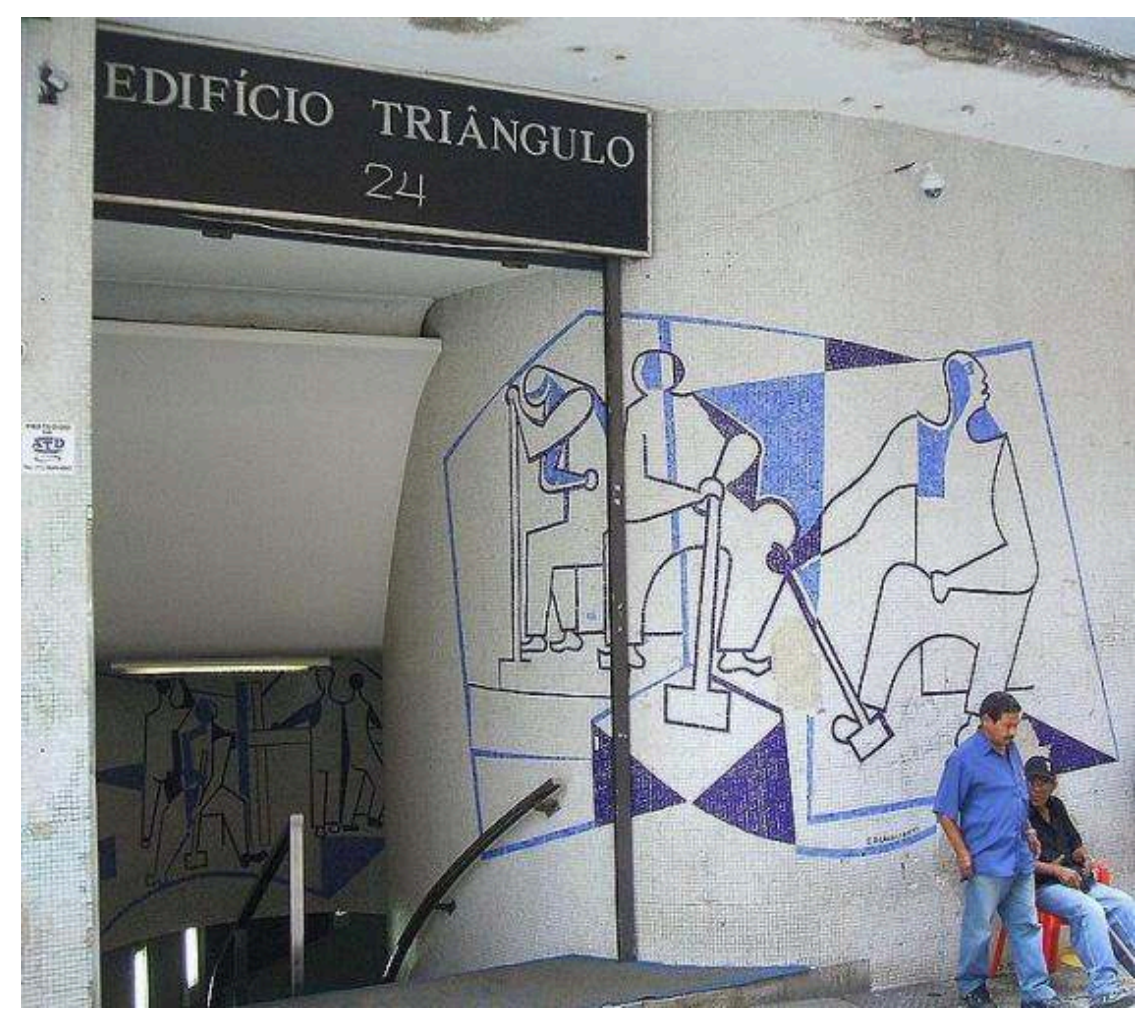


Figura 7 - Edifício Triângulo

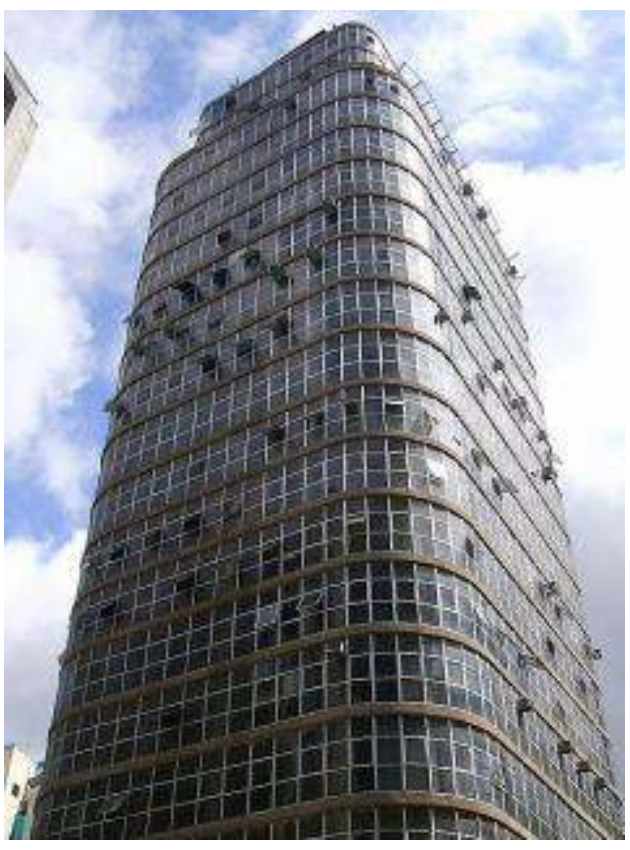

57 Projetado por Jaques Pelo, o edifício que abrigou o antigo Hotel Jaraguá, e a sede do jornal O Estado de São Paulo, possui elementos painéis de Di /Cavalcanti e Clóvis Graciano. Foi inaugurado por ocasião das festividades do IV Centenário em 1954 e marcou, graças a sua localização estratégica, a paisagem da cidade.

Figura 8 - Hotel Jaraguá

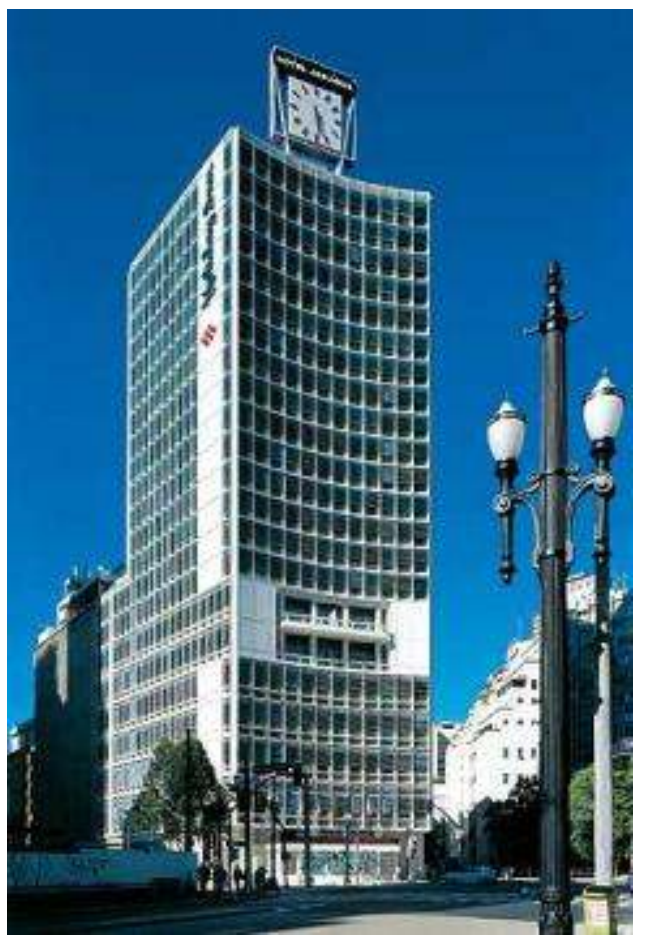


Figura 9 - Mosaico Hotel Jaraguá- Esquina Rua Martins Fontes com Rua Major Quedinho

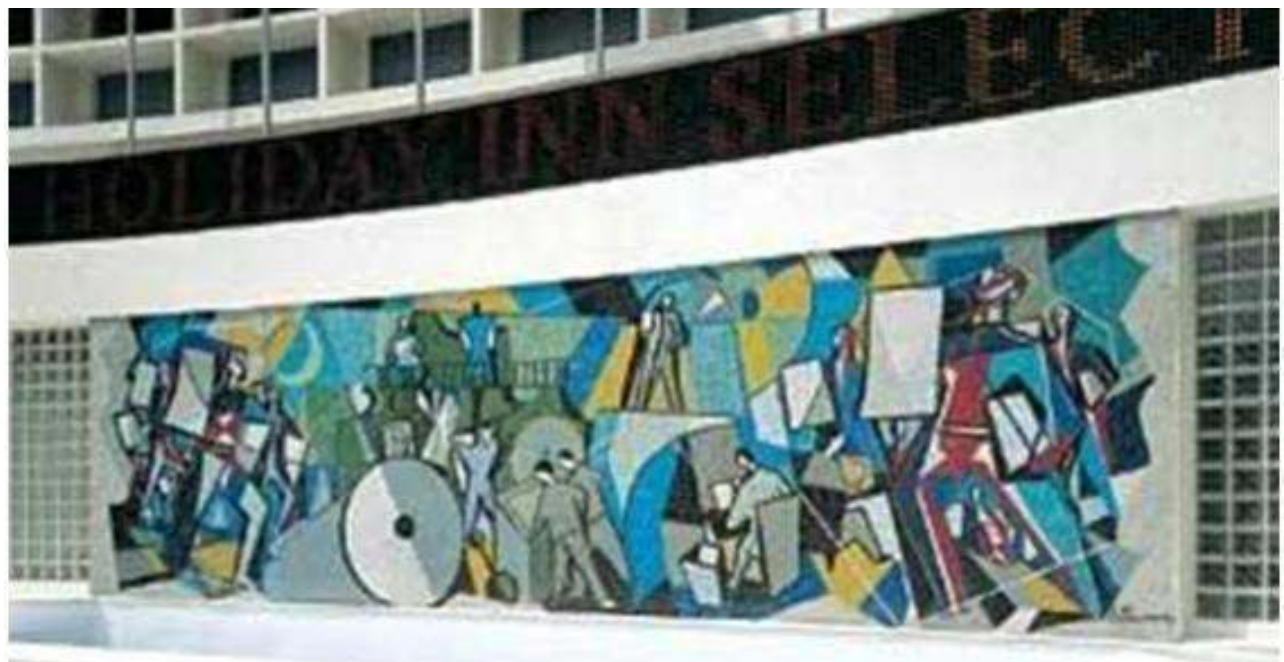

Outro notável exemplo de formulação arquitetônica com influência das discussões sobre síntese das artes é o teatro Cultura Artística, também em São Paulo. 0 Teatro foi projetado pelo arquiteto Rino Levi e a obra custeada pela Sociedade de Cultura Artística. A obra de Di Cavalcanti ocupava integralmente a fachada do Teatro, numa extensão de 48 metros de largura por oito de altura, totalmente realizada em pastilhas de vidro.

Figura 10 - A fachada do Teatro Cultura Artística exibe o maior afresco existente de Di Cavalcanti, medindo 48 metros de largura por 8 de altura, feito em mosaico de vidro

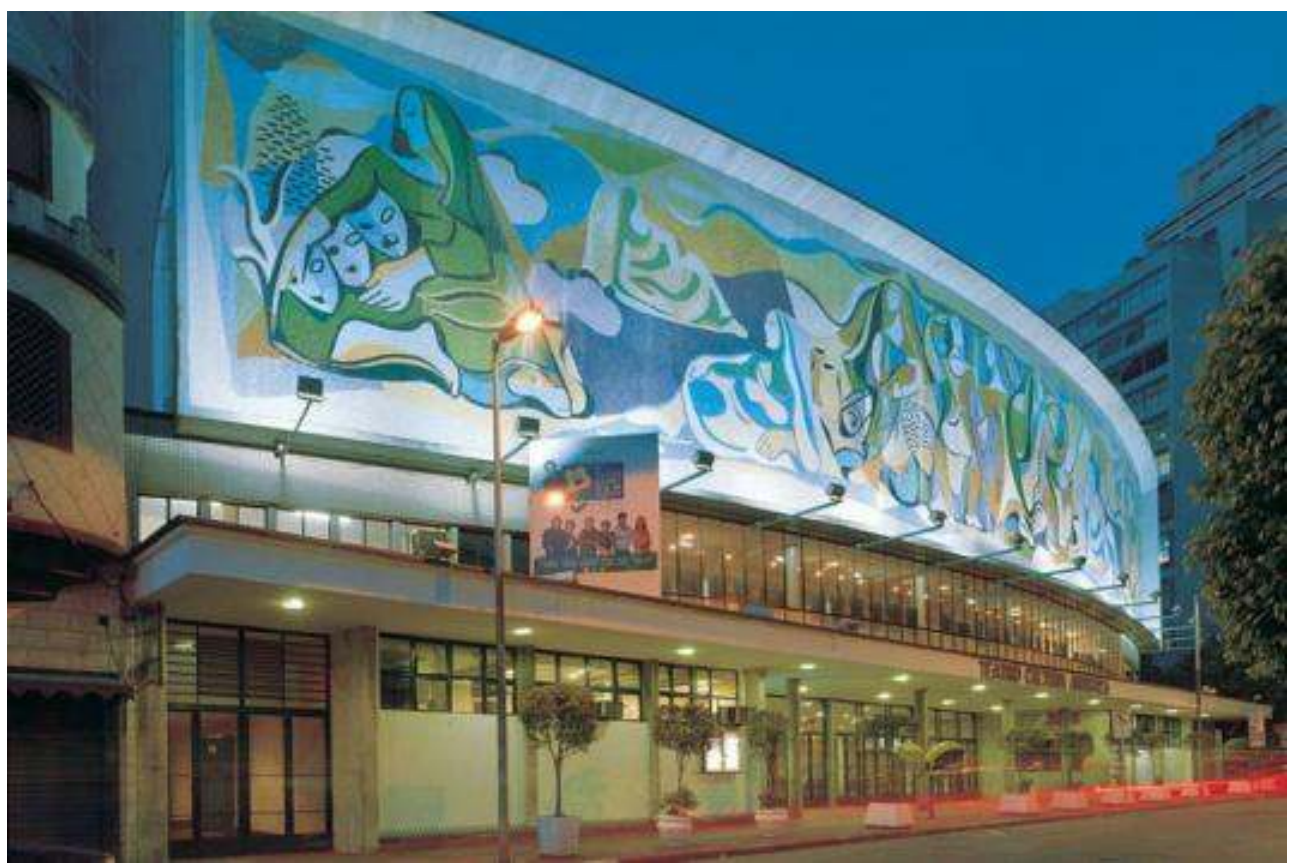




\section{A experiência da Unilabor : Produção fabril e síntese das artes}

59 A experiência de Geraldo de Barros na fábrica Unilabor representa uma tentativa de efetivar no plano nacional o ideal construtivo de integração da arte na vida cotidiana disseminado pela escola alemã Bauhaus nos Anos 1920.

Unilabor funcionou entre 1950 e 1967, tratava-se de uma associação entre artesãos marceneiros e serralheiros e o artista Geraldo de Barros, que desenhava os móveis. A fábrica era gerida pelos próprios trabalhadores e viabilizava não apenas o "ganha-pão", mas também o crescimento cultural e artístico de cada um.

61 Barros trabalhava com um conjunto reduzido de peças modulares produzido com um número restrito de materiais a partir de formas geométricas simples, tendo sempre em vista o mobiliário residencial. A variedade era conseguida mediante o arranjo diferenciado das mesmas peças. $\mathrm{O}$ sistema era bastante semelhante às experiências da Bauhaus, nas quais a produção serial era pensada como portadora de qualidades estéticas e, ao mesmo tempo, como possibilidade de expansão da produção fabril. ${ }^{22}$

Figura 11 - Exemplo de Mobiliário produzido pela Unilabor

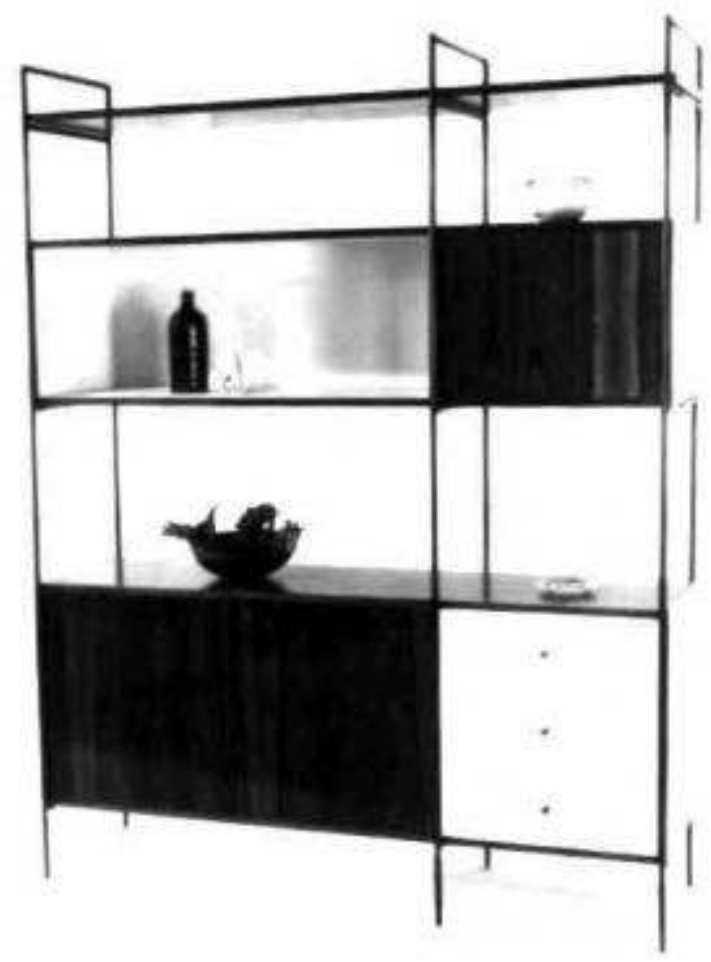


Figura 12 - 0 desenho dos móveis da Unilabor buscou a modulação das peças, visando aumentar a produção

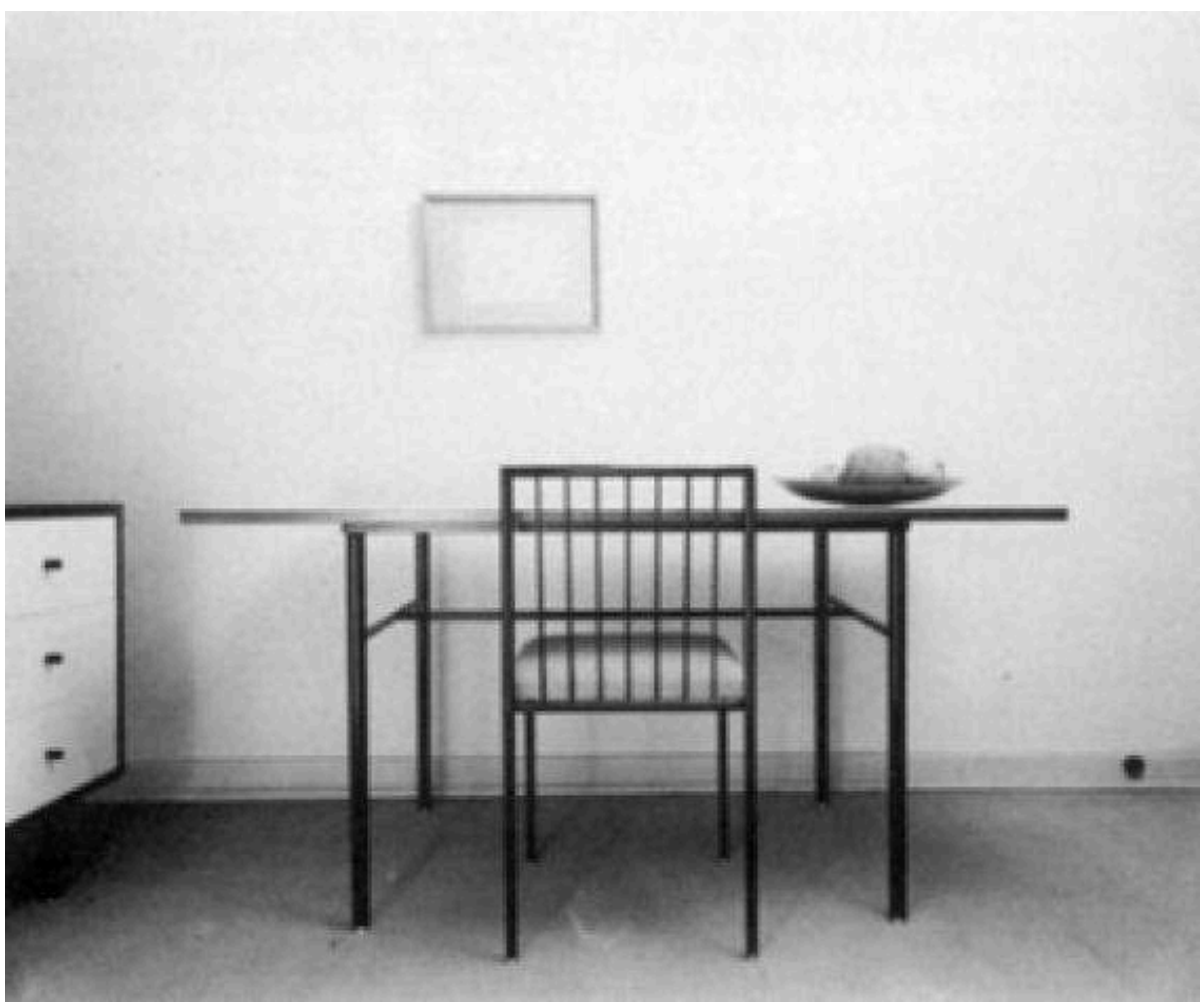

\section{Considerações finais}

O conceito de Obra de Arte Total do Romantismo possuía um lastro medieval da busca por uma comunidade perdida e um processo produtivo capaz de colaborar para a bildung, possibilitando ao artista artesão o desenvolvimento espiritual necessário à sua emancipação.

A apropriação deste conceito pelas Vanguardas Artísticas se fez de maneira a promover a ampliação de seu sentido último. Mais do que promover uma forma de produção industrial não alienada e portadora de um sentido estético, o conceito de síntese das artes para as Vanguardas apontou para o Homem, sua emancipação e a relação direta desta com o viver metropolitano. Afinal seria no anonimato da metrópole a possibilidade para que os homens livres realizassem suas trocas simbólicas.

Não seria então um erro pensar a arquitetura proposta pelas vanguardas como uma gesamtkunstwerk. A arquitetura seria a forma artística, síntese de todas as artes maiores, capaz de possibilitar a utopia moderna de dissolução da arte na vida.

O imaginário emancipatório desta operação, no qual uma Gesamtkunstwerk promoveria mais um passo no processo de emancipação e subjetivação modernas, se identifica diretamente com o ideário da "Educação Estética do Homem" proposto por Schiller, a partir de suas leituras de a "Crítica do juízo" de Kant. Schiller propõe que para alcançar a emancipação humana o estágio estético é condição necessária, pois este resgata as proposições de Kant sobre a faculdade de julgar do homem. 0 que significaria dizer que uma humanidade que não tivesse superado o estágio estético, seria incapaz de exercitar sua capacidade de julgar, e por extensão, incapaz de alcançar a emancipação. 

uma resposta às aporias da Modernidade - promover a construção de um espaço de subjetivação e emancipação humana. Sua práxis ocorreu nas mais diversas escalas, tanto no nível da cidade como no processo de produção industrial, mesmo tendo em vista o problema de se pensar síntese comunitária das artes em um momento no qual o individualismo exacerbado introduziu novas dificuldades para as propostas coletivas de emancipação modernas.

\section{BIBLIOGRAFIA}

BENEVOLO, Leonardo. História da Arquitetura Moderna. São Paulo : Perspectiva, 1989.

BRUAND, Yves. Arquitetura Contemporânea no Brasil. São Paulo : Perspectiva, 2002 . 
CAMPOFIORITO, Quirino. As artes plásticas na arquitetura moderna brasileira. In : XAVIER, Alberto. Depoimento de uma geração : arquitetura moderna brasileira (pp. 322-326). São Paulo : Cosac \& Naify, 2003.

CARPEAUX, Otto Maria. O livro de ouro da história da música. Rio de Janeiro : Ediouro, 2001.

CLARO, Mauro. Unilabor : Desenho Industrial, Arte Moderna e Autogestão Operária. São Paulo : SENAC, 2004.

COSTA, Lúcio. Registro de uma vivência. São Paulo : UnB / Empresa das Artes, 1995.

FERNANDES, Fernenda. A Síntese das Artes e a Moderna Arquitetura Brasileira dos anos 1950. Cadernos de Pós-Graduação da UNICAMP, v. 8. Campinas : UNICAMP, 2006.

FERNANDES, Fernanda. Arquitetura no Brasil no segundo pós-guerra - a síntese das artes. Rio de Janeiro : DOCOMOMO, 2005.

FRAMPTON, Kenneth. História crítica da arquitetura moderna. São Paulo: Martins Fontes, 2003.

GIEDION, Siegfried. Architecture You and Me. The diary of a development. Massachusetts: Harvard University Press, 1958.

LÉGER, Fernend. On Monumentality and Color. In: S. GIEDION, Architecture You and Me. The diary of a development (pp. 40-41). Massachusetts: Harvard University Press, 1958.

LOURENÇO, Maria Cecília França. Operários da modernidade. São Paulo : Hucitec/EDUSP, 1995.

MUMFORD, Eric. The CIAM Discourse on Urbanism, 1928-1960. Cambridge : MIT Press, 2000.

PEDROSA, Mário. Dos Murais de Portinari aos Espaços de Brasília . São Paulo : Perspectiva, 1980.

PRADO, Carlos da Silva. Da Boa Vizinhança entre as Artes Plásticas. Revista Acrópole n. 83 , pp. 301-302, 1945.

SCHORSKE, Carl Emil. Pensando com a História : Indagações na passagem para o Modernismo. São Paulo :Cia. das Letras, 2000.

SERT, Jose Luis. Centros para la vida de la comunidad. In : ROGERS, Ernesto Nathan ; SERT, Jose Luis \& TYRWHITT Jacqueline. El corazón de la ciudad: por una vida más humana de la comunidad (pp. 3-16). Barcelona : Editorial Científico-Médica, 1955.

SOMEKH, Nádia. Cidade Vertical e o Urbanismo Modernizador São Paulo : 1920-1939. São Paulo: STUDIO NOBEL, 1997.

ZUCKER, Paul. New Architecture and City Planning: A Symposium. New York: Philosophical Library, 1944.

\section{Fonte das Imagens}

Figura 1 - Painel de azulejos de Cândido Portinari. Disponível em http://pt.wikipedia.org/wiki/ Ficheiro:MESP3.jpg acessado 05/01/2010.

Figura 2 - Igreja da Pampulha. Disponível em http://pt.wikipedia.org/wiki/ Ficheiro:IgrejaPampulha.jpg acessado 05/01/2010.

Figura 3 - Painel de Azulejos de Cândido Portinari na Igreja da Pampulha. Disponível em http:// www.ceramicanorio.com/paineis/portinariigrejapampulha/portinariigrejapampulha.html acessado 05/01/2010. 
Figura 4 - O Eixo Monumental visto da Torre de TV de Brasília. Disponível em http:// pt.wikipedia.org/wiki/Ficheiro:Monumental_axis.jpg acessado 05/01/2010.

Figura 5 - O Meteoro, uma escultura em mármore de Bruno Giorgi, fica localizado em frente ao Palácio do Itamaraty. Disponível em http://pt.wikipedia.org/wiki/Ficheiro:Itamaraty.jpg

Figura 6 - Mural de Di Cavalcanti, na fachada do Edifício Triângulo. Disponível em http:// pt.wikipedia.org/wiki/Ficheiro:Edifício_Triângulo,_mural_Di_Cavalcanti_01.JPG acessado 05/01/2010.

Figura 7 - Edifício Triângulo.Disponível em http://pt.wikipedia.org/wiki/Edifício_Triângulo acessado 05/01/2010.

Figura 8 - Hotel Jaraguá. Disponível em http://img48.imageshack.us/img48/3958/ arquitetura4719dk.jpg acessado 05/01/2010.

Figura 9 - Mosaico Hotel Jaraguá- Esquina Rua Martins Fontes com Major Quedinho. Disponível em http://mosaicosdobrasil.tripod.com/id88.html acessado 05/01/2010.

Figura 10 - A fachada do Teatro Cultura Artística exibe o maior afresco existente de Di Cavalcanti, medindo 48 metros de largura por 8 de altura, feito em mosaico de vidro. Disponível em http:// www.vitruvius.com.br/minhacidade/mc230/mc230.asp acessado 05/01/2010.

Figura 11 - Exemplo de Mobiliário produzido pela Unilabor. Disponível em http://mcb.sp.gov.br/ mcbItem.asp?sMenu=P005\&sTipo=4\&sItem=301\&sOrdem=2 acessado 05/01/2010.

Figura 12 - O desenho dos móveis da Unilabor buscou a modulação das peças, visando aumentar a produção. Disponível em http://www.designbrasil.org.br/portal/almanaque/enciclopedia.jhtml? indice $=\mathrm{u}$ acessado $05 / 01 / 2010$

\section{NOTAS}

1. Obra de arte total.

2. Para Wagner a ópera seria a forma de manifestação artística única, capaz de colocar todos os meios artísticos a disposição a serviço de um espírito. Gesamtkunstwerk - obra de arte total - é um termo da língua alemã refere-se a um modo de fazer artístico - a ópera, capaz de conjugar música, teatro, literatura, dança e artes plásticas. Wagner acreditava que na antiga tragédia grega esses elementos estavam unidos, mas, em algum momento, separaram-se.

3. In CARPEAUX, Otto. O livro de ouro da história da música, p. 63

4. In SCHORSKE, Carl. Pensando com a História : Indagações na passagem para o Modernismo.

5. “A 'síntese das artes' é tema fundamental que percorre toda a problemática sobre a constituição da arquitetura moderna nas primeiras décadas do século XX. No plano internacional a questão já aparece no âmbito das Arts \& Crafts na Inglaterra de Morris, propondo uma arte que se estendesse a todas as esferas da sociedade, fazendo parte dos objetos de uso quotidiano e do ambiente da vida. Promovendo uma aproximação entre artes maiores e menores, o movimento busca, na revalorização do artesanato e na referência ao trabalho comunitário da Idade Média, caminhos de crítica à civilização industrial e ao alienante trabalho da indústria”. In : FERNANDES, Fernada. A Síntese das Artes e a Moderna Arquitetura Brasileira dos anos 1950, p. 71)

6. "Segundo o manifesto a adesão à 'obra de arte total' direcionaria um trabalho conjunto em que a arquitetura exerce papel fundamental como símbolo de uma espiritualidade nova e universal, a partir da qual se daria a reunificação das disciplinas artísticas erguidas como grande construção. Ao paradigma da máquina, até então vigente, sobrepõe-se aquele da catedral gótica, como local mítico onde se realizaria a obra total, fruto de diferentes contribuições regidas por um sentido de 
consenso e unidade". In FERNANDES, Fernanda. Arquitetura no Brasil no segundo pós-guerra-a síntese das artes, p. 6)

7. "A construção completa é o objetivo final das artes visuais. Sua função mais nobre, numa época, foi a decoração dos edifícios ; hoje sobrevivem em isolamento, do qual só podem ser retirados com os esforços conscientes e coordenados de todos os artífices. Os arquitetos, pintores e os escultores devem reconhecer o caráter compósito do edifício como uma entidade unitária. Só então seu trabalho se embeberá do espírito arquitetônico que agora, como 'arte de salão' ele perdeu.Todos nós arquitetos, escultores, pintores, devemos voltar-nos para nosso ofício. A arte não é uma profissão, não existe nenhuma diferença essencial entre o artista e o artesão... Formamos uma única comunidade de artífices sem a distinção de classe que levanta uma arrogante barreira entre artesão e o artista. Juntos concebemos e criamos o novo edifício do futuro, que reunirá arquitetura, escultura e pintura numa única unidade, e que uma dia será levantado contra o céu pelas mãos de milhões de trabalhadores como o símbolo de um cristal de uma nova fé". In GROPIUS, Walter apud BENEVOLO, Leonardo. História da Arquitetura Moderna, p. 404.

8. In FERNANDES, Fernanda. op. cit., p. 3

9. In FRAMPTON, Kenneth. História crítica da arquitetura moderna, p. 328

10. «Periods of real cultural life had always the capacity to project creatively their own image of society. They were able to build up their community centers (ágora, forum, mediaeval square) to fulfill this purpose. Our period, up to now, has proved itself incapable of creating anything to be compared with these institutions. There are monuments, many monuments, but where are the community centers? Neither radio nor television can replace the personal contact which alone can develop community life ». In GIEDION, Siegfried, in ZUCKER, Paul. New Architecture and City Planning: A Symposium, p.566.« Architecture, in every time, has been the means of plastic expression most sensitive to the people: the most visual, the most grandiose. It dominates the view and fixes the gaze ». In LÉGER, Fernand, in GIEDION, Siegfrid, Architecture You and Me. The diary of a development, p. 47.« People desire buildings that represent their social, ceremonial, and community life. They want these buildings to be more than a functional fulfillment. They seek the expression of their aspirations in monumentality, for joy and for excitement ». In GIEDION, Siegfried. op. cit., pp. 27-28)

11. FRAMPTON, Kenneth. op. cit. p. 270

12. « Sin dejar de reconocer las enormes ventajas y posibilidades de estos nuevos medios de telecomunicación, seguimos creyendo que los lugares de reunión pública, tales como plazas, paseos, cafés, casinos populares, etc., donde la gente pueda encontrarse libremente, estrecharse la mano y elegir el tema de conversación que sea de su agrado, no son cosas del pasado, y que, debidamente adaptadas a las exigencias de hoy, deben tener un lugar en nuestras ciudades ». In SERT, Jose Luis. Centros para la vida de la comunidad. In: ROGERS, Ernesto Nathan ; SERT, Jose Luis \& TYRWHITT Jacqueline. El corazón de la ciudad: por una vida más humana de la comunidad, p. 3.

13. "1. Cidade é a expressão palpável da humana necessidade de contacto, comunicação, organização e troca, - numa determinada circunstância physico-social e num contexto histórico. 2. Urbanizar consiste em trazer um pouco da cidade para o campo e trazer um pouco do campo para dentro da cidade. 3. Nas tarefas do engenheiro, o homem é principalmente considerado como um ser coletivo, como "número", prevalecendo o critério de quantidade ; ao passo que nas tarefas do arquiteto, o homem é encarado, antes de mais nada, como ser individual, como "pessoa", predominado então o critério de qualidade. Por outro lado, os interesses do homem como indivíduo nem sempre coincidem com os interesses desse mesmo homem como ser coletivo ; cabe então ao urbanista procurar resolver, na medida do possível, esta contradição fundamental". In COSTA, Lúcio. Registro de uma vivência, p. 277. 
14. "In order that architecture should be able to make use of it without any reservations, the wall had first to be freed to become an experimental field ». (LÉGER, Fernand. On Monumentality and Color in GIEDION, Siegfried. op. cit., p. 41).

15. In FERNANDES, Fernanda. op. cit..

16. "Desde o Ministério da Educação e Saúde até a Pampulha, há uma distância considerável, que mostra o caminho percorrido em alguns anos, e também, um evidente parentesco do ponto de vista estético. De fato a arquitetura brasileira desse período caracteriza-se pela sua leveza, audácia e graça, aliadas a uma grande força de expressão. Caracteriza-se ainda pela riqueza formal, quanto material, e por um efeito de síntese das artes, possível pelo fato de que nem sempre era necessário levar em conta os custos. Escultura, pintura mural e azulejos são o complemento quase obrigatório e, em geral, de grande efeito. Mas a arquitetura conserva a liderança ; é o arquiteto quem decide qual é o papel atribuído ao pintor, ou ao escultor, quem o posiciona no lugar adequado. A participação destes jamais afeta a parte estrutural do edifício, tendo sempre a decoração o objetivo de sublinhar o caráter de simples de vedação das paredes que nunca são portantes". In BRUAND, Yves. Arquitetura Contemporânea no Brasil, p. 115.

17. "Ora, o revestimento de azulejos no pavimento térreo e o sentido fluido adotado na composição dos grandes painéis tem a função muito clara de amortecer a densidade das paredes a fim de tirar-lhes qualquer impressão de suporte, pois o bloco superior não se apóia nelas mas nas colunas. Sendo o azulejo um dos elementos tradicionais da arquitetura portuguesa, que era nossa, pareceu-nos oportuno renovar-lhe a aplicação”. In COSTA, Lúcio. op. cit. p. 202.

18. "Na Pampulha e em Brasília, vamos ter a confirmação de que ao arquiteto Oscar Niemeyer cabe a primazia de haver proporcionado excepcionais oportunidades às artes plásticas, que não encontram, facilmente, rivais em outras realizações internacionalmente reconhecidas. A pintura, como a escultura e outras categorias da criatividade plástica contemporânea (...) ganham um desembaraço que irá, cada vez mais, marcando um novo entrosamento artístico - arquitetura/ artes plásticas - em nosso século, à semelhança dos mais famosos conjuntos culturais do passado". In CAMPOFIORITO, Quirino. As artes plásticas na arquitetura moderna brasileira, p. 324.

19. In PEDROSA, Mário. Dos Murais de Portinari aos Espaços de Brasilia, p. 334

20. “A hipótese de Brasília teria, portanto, o caráter de união e sua dimensão integradora estaria afinada, ainda segundo o crítico [Mário Pedrosa], à necessidade de reconstrução regional do país. A aspiração à síntese teria também a intenção de conferir às artes um papel social e cultural de primeiro plano na tarefa de reconstrução regional, funcionando como alternativa à arte individualista e incutindo no artista a dimensão de seu papel social. Brasília será talvez o último pretexto para se pensar a síntese das artes, que aqui aparece carregada de utopia transformadora". In FERNANDES, Fernanda. op. cit., p. 7.

21. "Na década de 1950, tanto em São Paulo como no Rio de Janeiro, uma série de obras arquitetônicas surge como resultado da hipótese de integração entre as artes através da arquitetura e da participação social do artista na constituição do ambiente urbano. A arquitetura realizada a partir destas formulações irá fornecer à cidade obras onde a arte participa do espaço público, colorindo-a com painéis e murais, reveladores do imaginário do período. Arte pública, que qualifica o espaço urbano e se oferece acessível aos seus habitantes". In FERNANDES, Fernanda. op. cit., p. 7.

22. In CLARO, Mauro. Unilabor : Desenho Industrial, Arte Moderna e Autogestão Operária. 


\section{RESUMOS}

A retomada das discussões sobre arquitetura e urbanismo dentro dos CIAM's, no segundo pósguerra, possibilitou o debate entre as a nova geração de arquitetos e os antigos membros dos CIAM's. O debate se centrava nas críticas da nova geração aos postulados da arquitetura moderna baseados na Carta de Atenas. O manifesto Nine Points on Monumentality, de 1943 pode ser encarado como o início deste debate, mesmo antes da retomada dos "Congressos". O manifesto tem o resgate da comunidade como um de seus temas centrais. O presente trabalho tem, portanto, a intenção de resgatar e discutir a presença da idéia de comunidade nas discussões sobre arquitetura e urbanismo nos CIAM's do Segundo Pós-Guerra.

La reprise des discussions sur l'architecture et l'urbanisme dans le CIAM d'après-guerre, a permis le débat entre la nouvelle génération d'architectes et les anciens membres du CIAM. Le débat a porté sur les critiques de la nouvelle génération aux principes de l'architecture moderne, fondée sur la Charte d'Athènes. Le manifeste de neuf points sur la monumentalité, de 1943, peut être considéré comme le début de ce débat, avant même la reprise des «Congrès ". Le manifeste a la récupération de la communauté comme l'un de ses thèmes centraux. Ce travail vise donc récupérer et discuter la présence de l'idée de communauté dans les débats sur l'architecture et l'urbanisme des années d'après-guerre.

\section{ÍNDICE}

Palavras-chave: síntese das Artes, vanguardas artísticas, arquitetura brasileira, arquitetura moderna, nova monumentalidade, core

Mots-clés: synthèse des Arts, avant-gardes artistiques, architecture brésilienne, architecture moderne, nouvelle monumentalité, couleur

\section{AUTORES}

\section{MARCOS ANTONIO DOS SANTOS}

Arquiteto pela Universidade Estadual Paulista Júlio de Mesquita Filho. Mestre pelo Departamento de Arquitetura e Urbanismo da Escola de Engenharia de São Carlos - Universidade de São Paulo, desde 2008. Doutorando pela mesma instituição desde 2009. Desenvolve pesquisa em Arquitetura e Urbanismo, com ênfase em História com a temática : Arquitetura Moderna no Brasil, Arquitetura e Urbanismo das Vanguardas Européias marcosdossantos[at]usp.br

\section{CARLOS ALBERTO FERREIRA MARTINS}

Doutor pela Escuela Técnica Superior de Arquitectura - Universidad Politécnica de Madrid (1992). Livre-Docente pela EESC USP (1998). É Professor Titular (2006) e Chefe do Departamento de Arquitetura e Urbanismo da EESC-USP São Carlos. Coordena a Coleção Fontes da Arquitetura Moderna da Editora Cosac Naify. Presidente da Associação Nacional de Pesquisa e Pós-Graduação em Arquitetura e Urbanismo - ANPARQ. Professor Titular, pesquisador, orientador de Mestrado e Doutorado e Chefe do Departamento de Arquitetura e Urbanismo da EESC USP São Carlos. cmartins[at]sc.usp.br 